\title{
Improving the quality properties and extension the shelf life of soy cheese.
}

Nadra, S. Y. Hassan, Amany, M. El-Deeb and Sayed-Ahmed, E.F.

Food Technology Research Institute, Agricultural Research Center, Giza, Egypt.

\begin{abstract}
This study was to improving properties and enhancing the shelf life of soy cheese. Cheeses made from soymilk (100\%) or soymilk blended with fresh skim milk (75\%:25\%) was storage in brine solutions ( 5 and $10 \mathrm{~g} / 100 \mathrm{ml} \mathrm{NaCl}$ ) for 60 days at $5 \pm 1^{\circ} \mathrm{C}$. Chemical, microbiological, textural and Sensory evaluation was carried out during storage time at fresh, one and two months.

Moisture, ash, total nitrogen (TN), soluble nitrogen ( $\mathrm{SN}$ ), salt and yield contents were significantly $(\mathrm{P}<0.05)$ affected by blended with skim milk and brine concentrations used in the experimental cheeses at fresh and during storage. Minerals $(\mathrm{Ca}, \mathrm{P}, \mathrm{K}$ and $\mathrm{Zn}$ ) in soy cheese blended with $25 \%$ fresh skim milk (D treatment) recorded the highest values at in comparing to soy cheese (A treatment). The PH values showed little decreased in brined soy cheese at fresh in 5 and $10 \% \mathrm{NaCl}$ solutions. Microbiological properties showed that slightly decreased in the log counts of Lactobasillis bulgaricus and Streptococcus. thermophilus of brined soy cheese in all treatments and reaching the lowest count after two months of storage and no significant $(\mathrm{P}>0.05)$ changes between treatments in total bacterial counts at fresh. Firmness recorded increased values at fresh in $\mathrm{A}, \mathrm{B}$ and $\mathrm{C}$ treatments in compared to C, D and E treatments, while Cohesiveness, Gumminess, Chewiness and Resilience values were decreased during storage period of all soy cheese treatments. The proportion of fresh skim milk $(25 \%)$ used in soy cheese significantly $(p<0.05)$ influenced on sensory characteristics and improved generally at fresh and during storage compared to soy cheese $(100 \%$ soymilk). Also, treatments storage in 5 and $10 \%$ brine solutions at $5 \pm 1{ }^{\circ} \mathrm{C}$ enhancing the shelf life up to 60 days of storage period.
\end{abstract}

KEY WORDS: Soy cheese, Shelf life, Brine solution, Chemical analysis, Texture, Sensory evaluation.

\section{INTRODUCTION}

In recent years, the consumption of soymilk and soy curd has increased, perhaps owing to the perceived health problems associated with the high consumption of animal products (Chikpah et al., 2015).

For consumers, soymilk is popular as the type of milk that is most closely related to dairy milk among non-dairy milk products. Soymilk has nearly the same nutritional proportions as cow's milk, including $3.5 \%$ protein, $2 \%$ fat, $2.9 \%$ carbohydrate, and $0.5 \%$ ash and it is also rich in vitamins, and minerals (Raja et al., 2014). In dairy industry, soymilk and soybean proteins compete with dairy and milk proteins as a lowcost substitute. Among vegetable proteins, soybean is a protein rich food with a good balance of amino acids and desirable fatty acids (Rinaldoni $\boldsymbol{e t}$ al., 2014). 
Modern soy cheeses are prepared from soymilk, which is used for whole or partial replacement of cow's milk and/or other types of milk. Soy cheese has the benefits of high nutritive value, low cost, availability, suitability for those with lactose intolerance, and has been used in the treatment of protein deficiency among undernourished children. The main barrier of the taste of the soymilk products are its beany taste, which does not welcome by the consumers. In addition, the grainy texture diminishes the textural quality of cheese spreads made from soy sources while the dairy cheese spreads remain smooth and uniform (Qinghui et al., 2013). Soymilk cheese has been used as a soft cheese-like product (Liong et al., 2009).

Soy cheese as a medium has all the necessary conditions to facilitate LAB and other flavouring microorganisms to produce good cheese flavor and reduce bitter flavour. New combinations of cultures will be helpful for flavour improvements in soy cheese. Literature indicates that flavour-enhancing cultures like Lactococcus lactis ssp. lactis (formerly L. lactis ssp. Lactis biovar. diacetylactis), Lactobacillus helveticus, Lactobacillus casei, Streptococcus lactis ssp. maltigenes and Lactococcus lactis ssp. cremoris have the potential to improve soy cheese flavor (Ahmad et al., 2008).

It is important to develop a suitable processing system capable of providing the required textural, functional, and sensory properties of soy cheeses that closely resemble dairy cheese. Flavor development of soy cheese has attempted to reduce the unpleasant beany flavor by adding spices and other ingredients, or blending with other milk types. Using Lactobacillus spp .and Bifidobacterium spp., probiotic soy cheese types have been developed with improved nutritional quality (Jeewanthi and Paik, 2018).

Han et al., (2001) found that most types of sufu contain considerable levels of the antimicrobial $\mathrm{NaCl}(8-15 \%)$ that could prevent the survival or growth of pathogens. For public health reasons, the reduction of the salt level to $2-4 \%$ could cause a reduction of safety of soy cheese. Therefore, the addition of lactic acid bacteria, especially probiotics, was expected to ensure a rapid initiation of the fermentation process and decline in $\mathrm{pH}$ (Liu et al., 2006).

Texture defects associated with low salt levels include a soft, weak, pasty body, and suggest excessive proteolysis; at high salt levels, the cheese body becomes excessively firm, probably as a consequence of the lower proteolysis and lower degree of casein hydration (Guinee and Fox 2004).

The Cheddar cheese had the highest hardness, firmness and Young's modulus values (126.8, 98.81 N and 953.3 KPa, respectively), with some of the plant-based products showing similar textural properties to the Cheddar cheese. Furthermore, rheological analysis showed that the melt ability profiles of the plant-based products differed to those of Cheddar cheese (Grasso et al., 2021). 
The objective of this study was to improving sensory, microbiology, texture properties and prolong the shelf life of soy cheese by adding $25 \%$ of fresh skim milk and stored in brined solutions $(5$-and $10 \% \mathrm{NaCl})$ for 60 days at $5 \pm 1{ }^{\circ} \mathrm{C}$.

\section{MATERIALS AND METHODS}

\section{Materials:}

Yellow soybeans (Glycine max (L.) seeds were obtained from soy processing unit, Food Tech. Res. Inst., Agric. Res. Cent. Giza, Egypt.

Fresh buffaloes' skim milk was obtained from Faculty of Agriculture, Cairo University (0.5\% fat and $8.75 \%$ SNF).

Yoghurt culture Direct Vat Set (DVS) of Lactobacillus delbrueckii ssp. bulgaricus and Streptococcus thermophilusin the ratio (1:1) were obtained from Chr. Hansen's Lab., Copenhagen, Denmark.Rennet powder were obtained from Chr. Hansen's Lab., Denmark.

\section{Methods:}

\section{Preparation of soybean milk:}

Soybean milk (1:7w/v) contain $7.23 \%$ total solids, $1.48 \%$ fat and $3.17 \%$ protein was prepared in soy processing unit. (Food Technol. Res. Inst., Agric. Res. Cent., Giza, Egypt) according to the method described by Tanteeratarm et al., (1993).

\section{Soy cheese preparation:}

Two treatments of soy soft cheese were manufactured using the following procedure:

1- Soybean milk was heated to $90^{\circ} \mathrm{C}$ for $10 \mathrm{~min}$ and calcium chloride was added to hot milk

(5g/kg milk). Milk was cooled to $40^{\circ} \mathrm{C}$ and yoghurt starter (L. delbrueckii ssp.

bulgaricus and Streptococcus thermophiles) was added at ratio of 3\% followed by liquid rennet $\left(1 \mathrm{ml} / \mathrm{kg}\right.$ milk). Incubation was carried out at $40^{\circ} \mathrm{C}$ until firm coagulum was received. The resulting soy cheese was mixed with $3.0 \%$ salt and transferred to moulds for draining and pressing (about $20 \mathrm{hrs).} \mathrm{After} \mathrm{pressing,} \mathrm{cheese} \mathrm{was} \mathrm{cut} \mathrm{into} \mathrm{cubes} \mathrm{of}$ the size 3.0X3.0X1.5 cm., packed in plastic refills and stored in a pasteurized brine solutions ( 5 and $10 \% \mathrm{NaCl}, \mathrm{w} / \mathrm{v})$ at $5 \pm 1^{\circ} \mathrm{C}$ for 60 days. 
Soybeans

$\downarrow$ washing by tap water

Soaking in tap water

(Containing $0.25 \% \mathrm{NaHCO} 3$ at room temperature for $5 \mathrm{hrs}$.)

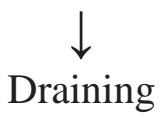

$\downarrow$

Blanching in boiling water with $0.05 \% \mathrm{NaHCO}_{3}$

Rinsing with boiled tap water

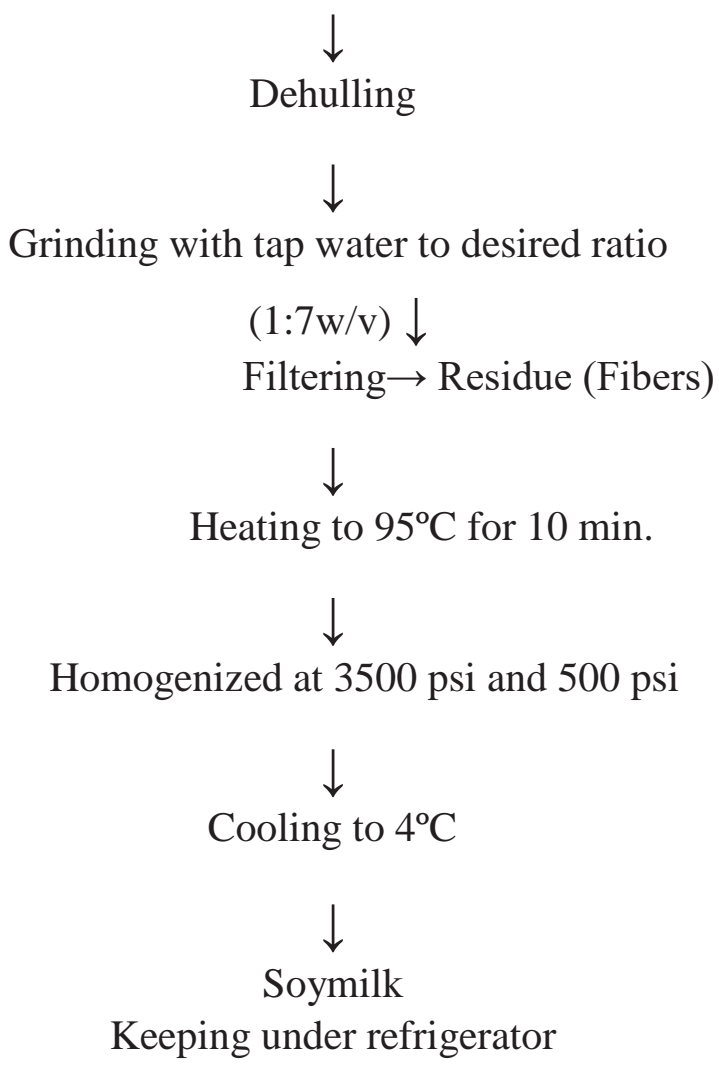

Fig.1. Preparation of soymilk

2- Milk mixture ( $75 \%$ soymilk $+25 \%$ fresh skim milk) was heated to $75^{\circ} \mathrm{C}$ for 5 min., and then could to $40^{\circ} \mathrm{C}$; calcium chloride was added to $(0.02 \%$ for skim milk and $0.5 \%$ for soymilk). Yoghurt starter was added at ratio of 3\% followed 
by liquid rennet $\left(1 \mathrm{ml} / \mathrm{kg}\right.$ milk) and kept at $40^{\circ} \mathrm{C}$ until firm curd was obtained.

Salting and all other steps were applied as previously mentioned.

Six treatments of soy cheese made from soymilk or with skim milk (25\%) mixtures as follows:

A: Soy cheese made from $100 \%$ soymilk (Control)

B: Treatment A brined in $5 \% \mathrm{NaCl}$

C: Treatment A brined in $10 \% \mathrm{NaCl}$

D: Soy cheese made from $75 \%$ soymilk $+25 \%$ skim milk

E: Treatment $\mathrm{D}$ brined in $5 \% \mathrm{NaCl}$

F: Treatment $\mathrm{D}$ brined in $10 \% \mathrm{NaCl}$

All treatments were analyzed in duplicate at fresh, 30 and 60 days of refrigerated storage period.

The yield of cheese was calculated as kg curd / 100kg soybean milk.

\section{Chemical analysis of soy cheese:}

Soy cheese samples were chemically analyzed when fresh and after 1 and 2 months of cold storage at $5 \pm 1^{\circ} \mathrm{C}$ for total solids, ash, total nitrogen (TN) and soluble nitrogen (SN), were determined according to AOAC (2012). Minerals (Na, Ca, K, P, Fe and $\mathrm{Zn})$ were determining according to Kirk and Sawyer (1991). Weight the sample and ash was prepared in muffle furnace. The stock solution was prepared by using hydrochloric acid and then minerals were determined by using the Atomic Absorption Spectrophotometer (AAS), model: (Varian Model Spectra AA 100 \& 200). PH values(using $\mathrm{pH}$ meter model HANNA 8417) and titratable acidity were measured as described in AOAC (2012).

\section{Microbiological properties of soy cheese:}

Cheese samples were analyzed for Lactobacillus delbrueckii ssp. bulgaricus and Streptococcus thermophilus counts according to the methods described by Tharmaraj and Shah (2003). Total bacterial counts (TBC) and yeasts \& moulds of soy cheese were counted according to Marshall (1992). 


\section{Textural properties of soy cheese:}

Texture was determined by a universal testing machine (Cometech, Type, Taiwan) provided with software. An Aluminum $50 \mathrm{~mm}$ diameter cylindrical probe was used in a " Texture Profile Analysis" (TPA) double compression test to penetrate to $40 \%$ depth, at $1 \mathrm{~mm} / \mathrm{s}$ speed test. Firmness, Cohesiveness, gumminess, chewiness, springiness and resilience were calculated from the TPA graphic. Both springiness and resilience, give information about the after stress recovery capacity, while the former refers to retarded recovery, the latter concerns instantaneous recovery (immediately after the first compression, while the probe goes up) (Bourne, 2003).

\section{Sensory evaluation of soy cheese:}

The sensory evaluation of soy cheese were evaluated by 10 judges of staff members of Food Technol. Res. Inst., Agric. Res. Cent., Giza, according to Wang and Du (1998). Evaluation was based on five features, such as colour, flavor, appearance, texture and aroma resulting in a maximum of five points for each characteristic.

\section{Statistical analysis:}

Statistical analysis of the obtained data was performed according to SAS Institute

(1990) using liner Model (GLM). Duncan's multiple rang was used to separate among means of three replicates of the data.

\section{RESULTS AND DISCUSSION}

\section{Chemical properties of soy cheese:}

Mean values obtained from the experimental soy cheese $(100 \%$ soy milk or blended with $25 \%$ fresh skim milk) brined with different $\mathrm{NaCl}$ concentrations (5 and 10\%) during storage for 60 days at $5 \pm 1{ }^{\circ} \mathrm{C}$ are presented in Table 1 .

It was observed that total solids, ash, TN, SN, salt and yield contents were significantly $(\mathrm{P}<0.05)$ affected by blended with skim milk and brine concentrations used in the experimental cheeses. Total solids of brined soy cheese (BSC) was significantly increased by the addition of $25 \%$ fresh skim milk, it was ranged from 25.41 to $28.16 \%$ at fresh.

This finding could attributed at first to higher water binding capacity of soybean proteins comparably with milk casein as confirmed by Wolf (1970). Data in agreement with Chikpah et al., (2016) who mentioned that the blending of cow soymilk significantly $(\mathrm{p}<0.05)$ influenced the moisture content of the West Africa soft cheese (WASC) products and increased with increasing percentage of soymilk. Soy cheese treatments was significantly $(\mathrm{p}<0.05)$ influenced by the brine concentration $(5$ and $10 \% \mathrm{NaCl}$ ) and showed a slightly increased of total solids values after 30 days of storage, then decreased after 60 days of cold storage. The dry matter contents of the cheeses increased slightly possibly due to the penetration of salt from the brine to the cheese and serum passage from the cheese to the brine (Dagdemir et al., 2003; Kayagil and Gurakan 2009). 
Cheese samples produced by coagulating cow and soya milk blends at different $\mathrm{pH}$ were stored in 8, 9 and $10 \%$ brine and were examined after 1, 10 and 20 days had a significant effect on cheese DM content(Hursit and Temiz, 2000).

Also Guinee (2004) recorded that at a low brine concentration (e.g., $7 \% \mathrm{NaCl}$ ), water is transferred from the brine into the cheese to achieve osmotic pressure equilibrium. During brining, the quantity of $\mathrm{NaCl}$ that is absorbed by the cheese, and consequently the cheese sodium content, depends on several parameters such as brine concentration, salting time, cheese moisture, and cheese $\mathrm{pH}$ (Kaminarides et al., 2019).

The proportion of soy and skim milk used for soy cheese treatments did not significantly $(p>0.05)$ affect the total ash content at fresh. On the other hand, (Kaminarides, et al., 2019) found ash values were increased during storage period with similar results. These results agreement with (Ayyash et al., 2012) who reported that the migration of salt from the brine solution toward the cheese increased $(\mathrm{P}<0.05)$ the ash content during the storage period for the same salt treatment. Similar results are reported by (Krishna, 2003).

Mean values of nitrogen factions (total nitrogen (TN) and soluble nitrogen (SN) and S.N/T.N \%) in soy cheese are shown in Table (1). Data showed no significant difference was observed between experimental soy cheeses at the same storage period. A significant difference was observed in soluble nitrogen and S.N/T.N\% during storage at $5 \pm 1^{\circ} \mathrm{C}$.

Water-soluble nitrogen showed a significant $(P<0.05)$ increase during storage for the same salt treatment in Akawi cheese (Ayyash et al., 2012). Also Data showed SN (\%) of all samples showed significance $(P<0.05)$ differences during 60 days of storage period and increased until the end of ripening period in agreement with (Lavasani, 2016).

The contents of water soluble nitrogen (WSN) as a percentage of total nitrogen (TN) in the experimental cheeses increased significantly $(\mathrm{P}<0.05)$ up to day 30 of ripening, then remained almost constant during the rest of the storage period (Bakirci et al., 2011).

The different salt concentrations had significant $(\mathrm{P}<0.05)$ effect on the level of WSN/TN in the cheeses, probably due to the inhibitory effect of salt on bacterial growth and enzyme activity (Banks, 1992). Similar results were reported Guven and Karaca (2001) for white cheeses salted and ripened in brines and (Hayaloglu et al., 2005) for Turkish white-brined cheese.

A marked increase was observed in salt content in soy cheese treatments during storage period in all samples $(P<0.0 .5)$. The $\mathrm{NaCl}$ concentration from the brine cheese is increasing during the maturation time, especially in the first 5 days (1.5 times higher), subsequent the increasing rate is diminished reported by (Rotaru et al., 2008). Increasing in salt content during ripening in Iranian white brined cheese could be attributed to the large gradient concentration between curd and brine at first month of ripening period. (Alizadeh and Lavasani, 2013). 
Brined cheese is stored in concentrated brine $(4-16 \% \mathrm{NaCl})$, at temperatures lower than $8^{\circ} \mathrm{C}$ and can be preserved for more than three months even up to 15 months (Erdem, 2005).

Table (1). Chemical composition of soy cheese during storage during storage at $5 \pm 1^{\circ} \mathrm{C}$

\begin{tabular}{|c|c|c|c|c|c|c|c|}
\hline $\begin{array}{l}\text { Properties } \\
(\%)\end{array}$ & storage & $\bar{A}$ & $\bar{B}$ & $\bar{C}$ & D & $\mathbf{E}$ & $\mathbf{F}$ \\
\hline \multirow[t]{3}{*}{ T.S } & Fresh & $25.41 \pm 0.54^{\mathrm{C}}$ & $25.74 \pm 0.24^{c}$ & $25.86 \pm 0.17^{\mathrm{Cc}}$ & $27.86 \pm 0.25^{\mathrm{B}}$ & $27.90 \pm 0.20^{\mathrm{Bc}}$ & $28.16 \pm 0.19^{\mathrm{Ac}}$ \\
\hline & 1month & - & $27.89 \pm 0.31^{\mathrm{Da}}$ & $28.54 \pm 0.30^{\mathrm{Ca}}$ & - & $30.39 \pm 0.44^{\mathrm{Ba}}$ & $31.35 \pm 0.20^{\mathrm{Aa}}$ \\
\hline & 2month & - & $26.73 \pm 0.46^{\mathrm{Cb}}$ & $27.45 \pm 0.33^{\mathrm{Bb}}$ & - & $29.43 \pm 0.25^{\mathrm{Ab}}$ & $29.21 \pm 0.29^{\mathrm{Ab}}$ \\
\hline \multirow[t]{3}{*}{ Ash } & Fresh & $1.44 \pm 0.07^{\mathrm{A}}$ & $1.47 \pm 0.19^{\mathrm{Ac}}$ & $1.51 \pm 0.19^{\mathrm{Ac}}$ & $1.41 \pm 0.17^{\mathrm{A}}$ & $1.42 \pm 0.10^{\mathrm{Ac}}$ & $1.48 \pm 0.16^{\mathrm{Ac}}$ \\
\hline & 1month & - & $2.01 \pm 0.11^{\mathrm{Cb}}$ & $2.95 \pm 0.15^{\mathrm{Ab}}$ & - & $2.82 \pm 0.15^{\mathrm{Bb}}$ & $2.87 \pm 0.17^{\mathrm{Bb}}$ \\
\hline & 2month & -- & $3.45 \pm 0.20^{\mathrm{Ba}}$ & $4.37 \pm 0.27^{\mathrm{Aa}}$ & - & $3.52 \pm 0.19^{\mathrm{Ba}}$ & $3.73 \pm 0.21^{\mathrm{Ba}}$ \\
\hline \multirow{3}{*}{ T.N } & Fresh & $1.48 \pm 0.32^{\mathrm{A}}$ & $1.50 \pm 0.23^{\mathrm{Aa}}$ & $1.47 \pm 0.04^{\mathrm{Aa}}$ & $1.53 \pm 0.16^{\mathrm{A}}$ & $1.54 \pm 0.25^{\mathrm{Aa}}$ & $1.52 \pm 0.29^{\mathrm{Aa}}$ \\
\hline & 1month & - & $1.41 \pm 0.29^{\mathrm{Ab}}$ & $1.33 \pm 0.12^{\mathrm{Bb}}$ & - & $1.48 \pm 0.29^{\mathrm{Ab}}$ & $1.46 \pm 0.30^{\mathrm{Ab}}$ \\
\hline & 2month & - & $1.38 \pm 0.20^{\mathrm{Ac}}$ & $1.30 \pm 0.32^{\mathrm{Bc}}$ & - & $1.42 \pm 0.21^{\mathrm{Ac}}$ & $1.44 \pm 0.24^{\mathrm{Ac}}$ \\
\hline \multirow[t]{3}{*}{ S.N } & Fresh & $0.11 \pm 0.01^{\mathrm{A}}$ & $0.11 \pm 0.02^{\mathrm{Aa}}$ & $0.10 \pm 0.19^{\mathrm{Aa}}$ & $0.09 \pm 0.20^{\mathrm{A}}$ & $0.09 \pm 0.03^{\mathrm{Aa}}$ & $0.10 \pm 0.02^{\mathrm{Aa}}$ \\
\hline & 1month & - & $0.12 \pm 0.01^{\mathrm{Aa}}$ & $0.11 \pm 0.22^{\mathrm{Aa}}$ & - & $0.10 \pm 0.10^{\mathrm{Aa}}$ & $0.11 \pm 0.14^{\mathrm{Aa}}$ \\
\hline & 2month & - & $0.12 \pm 0.20^{\mathrm{Aa}}$ & $0.11 \pm 0.13^{\mathrm{Aa}}$ & - & $0.11 \pm 0.22^{\mathrm{Aa}}$ & $0.11 \pm 0.31^{\mathrm{Aa}}$ \\
\hline \multirow[t]{3}{*}{ S.N/T.N } & Fresh & $7.41 \pm 0.33^{A}$ & $7.30 \pm 0.21^{\mathrm{Ac}}$ & $6.77 \pm 0.08^{\mathrm{Bc}}$ & $5.93 \pm 0.14^{C}$ & $5.81 \pm 0.31^{\mathrm{Cc}}$ & $6.46 \pm 0.11^{\mathrm{Bc}}$ \\
\hline & 1month & --- & $8.32 \pm 0.37^{\text {Aab }}$ & $8.01 \pm 0.26^{\text {Aab }}$ & --- & $6.72 \pm 0.06^{\mathrm{Cb}}$ & $7.47 \pm 0.18^{\text {Bab }}$ \\
\hline & 2month & --- & $8.67 \pm 0.24^{\mathrm{Aa}}$ & $8.45 \pm 0.31^{\mathrm{Aa}}$ & --- & $7.71 \pm 0.16^{\mathrm{Ba}}$ & $7.62 \pm 0.25^{\mathrm{Ba}}$ \\
\hline \multirow[t]{3}{*}{ Salt } & Fresh & $0.73 \pm 0.21^{C}$ & $0.87 \pm 0.22^{\mathrm{Bc}}$ & $0.96 \pm 0.19^{\mathrm{Ac}}$ & $0.71 \pm 0.20^{\mathrm{C}}$ & $0.79 \pm 0.27^{\mathrm{Cc}}$ & $0.92 \pm 0.20^{\mathrm{Ac}}$ \\
\hline & 1month & - & $1.95 \pm 0.11^{\mathrm{Cb}}$ & $2.65 \pm 0.22^{\mathrm{Ab}}$ & - & $1.88 \pm 0.10^{\mathrm{Cb}}$ & $2.43 \pm 0.10^{\mathrm{Bb}}$ \\
\hline & 2month & - & $2.91 \pm 0.20^{\mathrm{Ba}}$ & $4.53 \pm 0.13^{\mathrm{Aa}}$ & - & $2.43 \pm 0.22^{\mathrm{Ca}}$ & $4.37 \pm 0.31^{\text {Aa }}$ \\
\hline Yield at Fresh & Fresh & $22.25 \pm 0.18^{\mathrm{B}}$ & ---- & ----- & $25.47 \pm 0.27^{\mathrm{A}}$ & ---- & - \\
\hline
\end{tabular}

A, B, C \& D and a, b, c \& d: means with the same letter among treatments and the storage period respectively are not significantly different $(\mathrm{P}>0.05)$.

A: Soy cheese made from Soymilk (Control)

A treatment brined in $5 \% \mathrm{NaCl}$

C: A treatment brined in $10 \% \mathrm{NaCl}$
D: Soy cheese made from $75 \%$ soymilk $+25 \%$ skim milk B:

$\mathrm{E}: \mathrm{D}$ treatment brined in $5 \% \mathrm{NaCl}$

F: D treatment brined in $10 \% \mathrm{NaCl}$ 
Table (1) shows the results of yield percentage of soy cheese blended with $25 \%$ of fresh skim milk were increased the yield compared with soy cheese treatment $(100 \%$ soymilk) ranged from 22.25 to $25.47 \%$.

In agreement with Lee $\boldsymbol{e t}$ al., (2015) they reported the yield of yogurt-cheeses made with added soymilk was decreased and the cutting point was delayed compared to yogurt-cheese made without soymilk.

Also Chikpah et al., (2016) reported that the yield of West Africa soft cheese (WASC) decreased with increasing proportion of soymilk. This study confirmed the findings of Igyor et al., (2006) that cheese yield declined as there were increased in soymilk supplementation.

The variations in the yield of fresh curd can be attributed to differences in milk composition since the composition of milk particular fat and protein contents affects cheese yield (Fox et al., 2000).

Because the lactic acid bacteria produced lactic acid in the fermentation of soymilk, it reduced the $\mathrm{pH}$ of the soymilk solution, which made the $\mathrm{pH}$ approach to the isoelectric point of the protein. That made the protein change its state from sol to gel, and the protein gel network contains water, so the soybean curd yield increased and reached its top at the ratio of 1:2 between CYY-122 and SVV-21 strains (Jianming, et al., 2013).

On the other hand, Hofi et al., (1976) reported that the yield of Domiati cheese made from a 4:1 mixture of buffaloes milk and soymilk dropped slightly, and weight losses during pickling were slightly higher than for buffaloes milk cheese.

Cheese stored through pickling at room temperature showed lower yield than the corresponding samples stored at low temperature (Abou Zeid et al., 2007). This may be due to the high acidity development in cheese at room temperature, which would inherence curd contraction. Also, the high yield at low temperature may result from the high ability of cheese proteins to absorb moisture at low temperature (AbdelKader 2003, Ismail, 2005). Part of the weight increase results from absorption of salt during brining, but most of the weight increase occurs because of absorption of brine into the cheese and a subsequent increase in volume (McMahon et al., 2009).

\section{Minerals contents (mg/100gm) of soy cheese:}

Minerals and trace elements represent less than one-half of one percent of the total nutrients we consume every day, and yet without them, our bodies would be unable to efficiently use the carbohydrates, proteins, and fats in our diet. Minerals play an essential role in the body. Many vitamins and enzymes need a mineral cofactor for proper function (Nazim et al., 2013).

The total concentrations of $\mathrm{Na}, \mathrm{Ca}, \mathrm{P}, \mathrm{K}, \mathrm{Fe}$ and $\mathrm{Zn}$ in experimental brined soy cheeses during the storage period at $5 \pm 1{ }^{\circ} \mathrm{C}$ are shown in Table (2).

Data showed that minerals ( $\mathrm{Ca}, \mathrm{P}, \mathrm{K}$ and $\mathrm{Zn}$ ) in soy cheese blended with $25 \%$ fresh skim milk (D treatment) recorded the highest values at fresh $(252.38,212.18,60.26$ and $1.81 \mathrm{mg} / 100 \mathrm{~g}$ ) in comparing to soy cheese made by $100 \%$ soy milk (A treatment: $198.35,187.41,57.11$ and $0.90 \mathrm{mg} / 100 \mathrm{~g}$ ), respectively 
Table (2). The concentrations of Minerals $(\mathrm{mg} / 100 \mathrm{~g})$ in soy cheese during storage at $5 \pm 1^{\circ} \mathrm{C}$

\begin{tabular}{|c|c|c|c|c|c|c|c|}
\hline Elements & Storage & $\mathbf{A}$ & B & $\mathbf{C}$ & D & $\mathbf{E}$ & $\mathbf{F}$ \\
\hline \multirow[t]{2}{*}{$\mathrm{Na}$} & Fresh & $1.81 \pm 0.03^{\mathrm{AB}}$ & $638.04 \pm 0.19^{\mathrm{ABb}}$ & $647.84 \pm 0.16^{\mathrm{Ab}}$ & $571.56 \pm 0.21^{\mathrm{C}}$ & $583.65 \pm 0.20^{\mathrm{Cb}}$ & $612.91 \pm 0.05^{\mathrm{Bb}}$ \\
\hline & 2month & - & $875.53 \pm 0.11^{\mathrm{Ba}}$ & $1342.86 \pm 0.04^{\mathrm{Aa}}$ & - & $794.17 \pm 0.11^{\mathrm{Ba}}$ & $1228.05 \pm 0.03^{\mathrm{Aa}}$ \\
\hline \multirow[t]{2}{*}{$\mathbf{C a}$} & Fresh & $198.35 \pm 0.11^{\mathrm{B}}$ & $196.43 \pm 0.11^{\mathrm{Ba}}$ & $194.72 \pm 0.06^{\mathrm{Ba}}$ & $252.38 \pm 0.10^{B}$ & $255.45 \pm 0.2^{\mathrm{Aa}}$ & $256.64 \pm 0.36^{\mathrm{Aa}}$ \\
\hline & 2month & - & $164.30 \pm 0.27^{\mathrm{Db}}$ & $17231 \pm 0.05^{\mathrm{Cb}}$ & - & $195.18 \pm 0.10^{\mathrm{Bb}}$ & $221.24 \pm 0.11^{\mathrm{Ab}}$ \\
\hline \multirow[t]{2}{*}{$\mathbf{P}$} & Fresh & $187.41 \pm 0.01_{\mathrm{BC}}$ & $190.44 \pm 0.10^{\mathrm{Ba}}$ & $192.58 \pm 0.11^{\mathrm{Ba}}$ & $212.18 \pm 0.20^{\mathrm{A}}$ & $215.98 \pm 0.16^{\mathrm{Aa}}$ & $218.55 \pm 0.20^{\mathrm{Aa}}$ \\
\hline & 2month & - & $176.34 \pm 0.11^{\mathrm{Bb}}$ & $171.51 \pm 0.21^{\mathrm{Bb}}$ & - & $179.13 \pm 0.10^{\mathrm{ABb}}$ & $183.42 \pm 0.18^{\mathrm{Ab}}$ \\
\hline \multirow[t]{2}{*}{$\mathbf{K}$} & Fresh & $57.11 \pm 0.10^{\mathrm{B}}$ & $55.13 \pm 0.22^{\mathrm{Ba}}$ & $53.31 \pm 0.13^{\mathrm{Ba}}$ & $60.26 \pm 0.10^{A}$ & $61.53 \pm 0.20^{\mathrm{Aa}}$ & $60.67 \pm 0.10^{\mathrm{Aa}}$ \\
\hline & 2month & - & $42.17 \pm 0.11^{\mathrm{Bb}}$ & $40.42 \pm 0.11^{\mathrm{Bb}}$ & - & $48.15 \pm 0.10^{\mathrm{Ab}}$ & $49.22 \pm 0.10^{\mathrm{Ab}}$ \\
\hline \multirow[t]{2}{*}{$\mathrm{Fe}$} & Fresh & $2.15 \pm 0.01^{\mathrm{A}}$ & $2.13 \pm 0.10^{\mathrm{Aa}}$ & $2.10 \pm 0.02^{\mathrm{Aa}}$ & $1.71 \pm 0.03^{\mathrm{B}}$ & $1.65 \pm 0.02^{\mathrm{Ba}}$ & $1.63 \pm 0.02^{\mathrm{Ba}}$ \\
\hline & 2month & -- & $1.68 \pm 0.21^{\mathrm{Ab}}$ & $1.78 \pm 0.15^{\mathrm{Ab}}$ & -- & $1.31 \pm 0.10^{\mathrm{Bb}}$ & $1.37 \pm 0.10^{\mathrm{Bb}}$ \\
\hline \multirow[t]{2}{*}{ Zn } & fresh & $0.90 \pm 0.02^{\mathrm{B}}$ & $0.92 \pm 0.03^{\mathrm{Ba}}$ & $0.91 \pm 0.01^{\mathrm{Ba}}$ & $1.81 \pm 0.03^{\mathrm{A}}$ & $1.84 \pm 0.03^{\mathrm{Aa}}$ & $1.87 \pm 0.03^{\mathrm{Aa}}$ \\
\hline & 2mon. & -- & $0.64 \pm 0.02^{\mathrm{Bb}}$ & $0 . .61 \pm 0.04^{\mathrm{Bb}}$ & ---- & $1.58 \pm 0.03^{\mathrm{Ab}}$ & $1.55 \pm 0.14^{\mathrm{Ab}}$ \\
\hline
\end{tabular}

A, B , C \& D and a, b, c \& d: means with the same letter among treatments and the storage period respectively are not significantly different $(\mathrm{P}>0.05)$.

A: Soy cheese made from Soymilk (Control)

B: A treatment brined in $5 \% \mathrm{NaCl}$

A treatment brined in $10 \% \mathrm{NaCl}$
D: Soy cheese made from $75 \%$ soymilk $+25 \%$ skim milk

E: D treatment brined in $5 \% \mathrm{NaCl} \mathrm{C}$ :

F: D treatment brined in $10 \% \mathrm{NaCl}$

Our data it the same line with Nazim et al., (2013) who reported that calcium is highly significantly $(\mathrm{p}<0.001)$ in cow milk cheese and we got only calcium that is higher in cow milk cheese but soy cheese also contain remarkable amount of calcium. Calcium is the most abundant macro-element in milk. Moreover, milk consumption contributes significantly to the dietary intake of other minerals such a sphosphorus, magnesium, zinc and selenium (Pereira, 2014). Calcium, $\mathrm{P}, \mathrm{K}, \mathrm{Fe}$ and $\mathrm{Zn}$ contents in experimental soy cheeses decreased significantly $(P<0.05)$ during the storage period for all treatments. This reduction may be due to the migration of minerals toward the brine solution. Sodium is significantly $(\mathrm{p}<$ 0.05) higher in A, Band $\mathrm{C}$ treatments than $\mathrm{D}, \mathrm{E}$ and $\mathrm{F}$ treatments due to soaking of soya cheese in sodium salt and $\mathrm{Na}$ content increased $(P<0.05)$ during the storage period for the same treatment, these results are in agreement with Ayyash et al., (2011).

\section{PH and Acidity of soy cheese:}

The changes of $\mathrm{pH}$ and the titratable acidity of brined soy cheese treatments $(100 \%$ soy milk or blended with $25 \%$ fresh skim milk) brined with deferent concentrations of $\mathrm{NaCl}(5$ and $10 \%)$ during storage at $\left(5 \pm 1^{\circ} \mathrm{C}\right)$ are given in Fig. 2 .

Data showed that brined soy cheese as affected in $\mathrm{pH}$ values in $\mathrm{A}$ and $\mathrm{D}$ treatments. The $\mathrm{pH}$ values showed little decreased in brined soy cheese at fresh in 5 and $10 \% \mathrm{NaCl}$ solution. All cheese samples went through gradual decreases in $\mathrm{pH}$ during the storage period (60 days). 
The $\mathrm{pH}$ values of Turkish white cheese samples were decreased up to 60 days of ripening

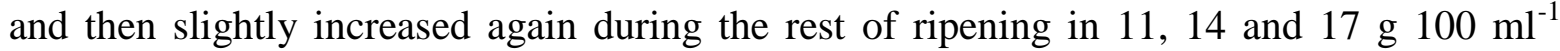
$\mathrm{NaCl}$ for 90 days at $7 \pm 1^{\circ} \mathrm{C}$ (Bakirci et al., 2011).

Sahingil et al.,(2014) reported that the $\mathrm{pH}$ decrease was independent from the ripening temperature, and the fastest and the slowest decreases in $\mathrm{pH}$ were noted in the cheese ripened at $12{ }^{\circ} \mathrm{C}$ and the cheese A ripened at $6{ }^{\circ} \mathrm{C}$, respectively stored in a pasteurized brine solution $(12 \% \mathrm{NaCl} \mathrm{w} / \mathrm{v})$ for 120 days.

Lower salt concentrations also allowed more generation of lactic acid and larger $\mathrm{pH}$ decreases during brining. In addition, cheeses brined at 6 and $10^{\circ} \mathrm{C}$ had intermediate $\mathrm{pH}$ decreases of 0.14 and 0.25 units, respectively (McMahon et al., 2009).

High levels of LAB in the product were correlated with significantly reduced $\mathrm{pH}$. However, product acidity above $4.6 \mathrm{pH}$ did not inhibit the growth of saprophytic microflora what is confirmed by generally high of total viable count (TVC) (Zielińska et al., 2015).

On the other hand, (Pastorino et al., 2003) reported that the $\mathrm{pH}$ values increased with the increasing salt concentrations of the cheese samples. This increase could be attributed to the inhibitory effect of salt concentration on the activities of lactic acid bacteria.

The changes in titratable acidity of brined soy cheese followed an opposite trend to $\mathrm{pH}$. Titratable acidity of the samples slightly increased throughout storage period and ranged from 0.81 to $1.22 \%$ as affected by brined concentrations ( 5 and $10 \%$ ). The proportion of skim milk and soymilk did not have any effect on the titratable acidity of product; the product was similar to the one obtained from skim milk (Park et al., 2005).

\section{Microbiological properties:}

The microbiological analysis of brined soy cheeses was carried out by plate counting during 1,30 and 60 days of storage at $\left(5 \pm 1^{\circ} \mathrm{C}\right)$ and the results are presented in Table 3.The results showed that there were significant $(\mathrm{P}<0.05)$ decreased in the log counts of Lb. bulgaricus and Str. thermophilus of brined soy cheese in all treatments and reaching the lowest count after 60 days of storage in B,E treatments(5\% brine solution) followed by $\mathrm{C}$ then $\mathrm{F}$ treatments (10\% brine solution). Counts of lactic acid bacteria (LAB) remained above of $10^{6}$ $\mathrm{cfu} / \mathrm{g}$ over the 60 days of storage in all brined cheese treatments.

It is possible to produce tofu with probiotic bacteria that has acceptable sensory characteristics and a high number of lactic acid bacteria (above $10^{9} \mathrm{CFU} / \mathrm{g}$ ) during 15 days of storage at $4^{\circ} \mathrm{C}$, therefore the product could be considered as a functional one (Zielińska $\boldsymbol{e t}$ al., 2015). Liong et al., (2009) found that the number of Lb. acidophilus FTCC 0291 in tofu during 20 days of cold storage was at the level above $10^{6} \mathrm{CFU} / \mathrm{g}$.

The viability of $L$. casei remained constant during ripening of white brined cheese (5\% $\mathrm{NaCl}$ ) over next 30 days (Kostoska et al., 2015).

In addition, Yilmaztekin et al., (2004) Investigating the survival of L. acidophilus LA-5 and B. bifidum BB-02 in white brined cheese and reported that total cell viability to be from $6.85^{\times} 10^{8}$ to $11.90^{\times} 10^{8} \mathrm{cfu} / \mathrm{g}$ after 30 days, and from $8^{\times} 10^{7}$ to $39,7^{\times} 10^{7} \mathrm{cfu} / \mathrm{g}$ after 60 days. 
The changes in counts of total bacteria during the storage period of brined soy cheese recorded almost equal values in all fresh soy cheese samples and changes between treatments were not significant $(\mathrm{P}>0.05)$. On the other hand, after 30 and 60 days of storage, there was a reduction in the number of total bacterial ( From 5.95 to $5.73 \log \mathrm{cfu} / \mathrm{g}$ ) in B, $\mathrm{C}, \mathrm{E}$ and $\mathrm{F}$ brined soy cheese samples.

When added to foods lactic acid bacteria increase microbiological safety of foods. It is associated with the fact that these bacteria produce organic acids as well as other substances with bacteriostatic properties (El-Shouny et al., 2013).

Also high viable counts of LAB are necessary to get the desired acid production and reduction in $\mathrm{pH}$, which affects organoleptic properties and shelf life of final products (Rathore et al., 2012).
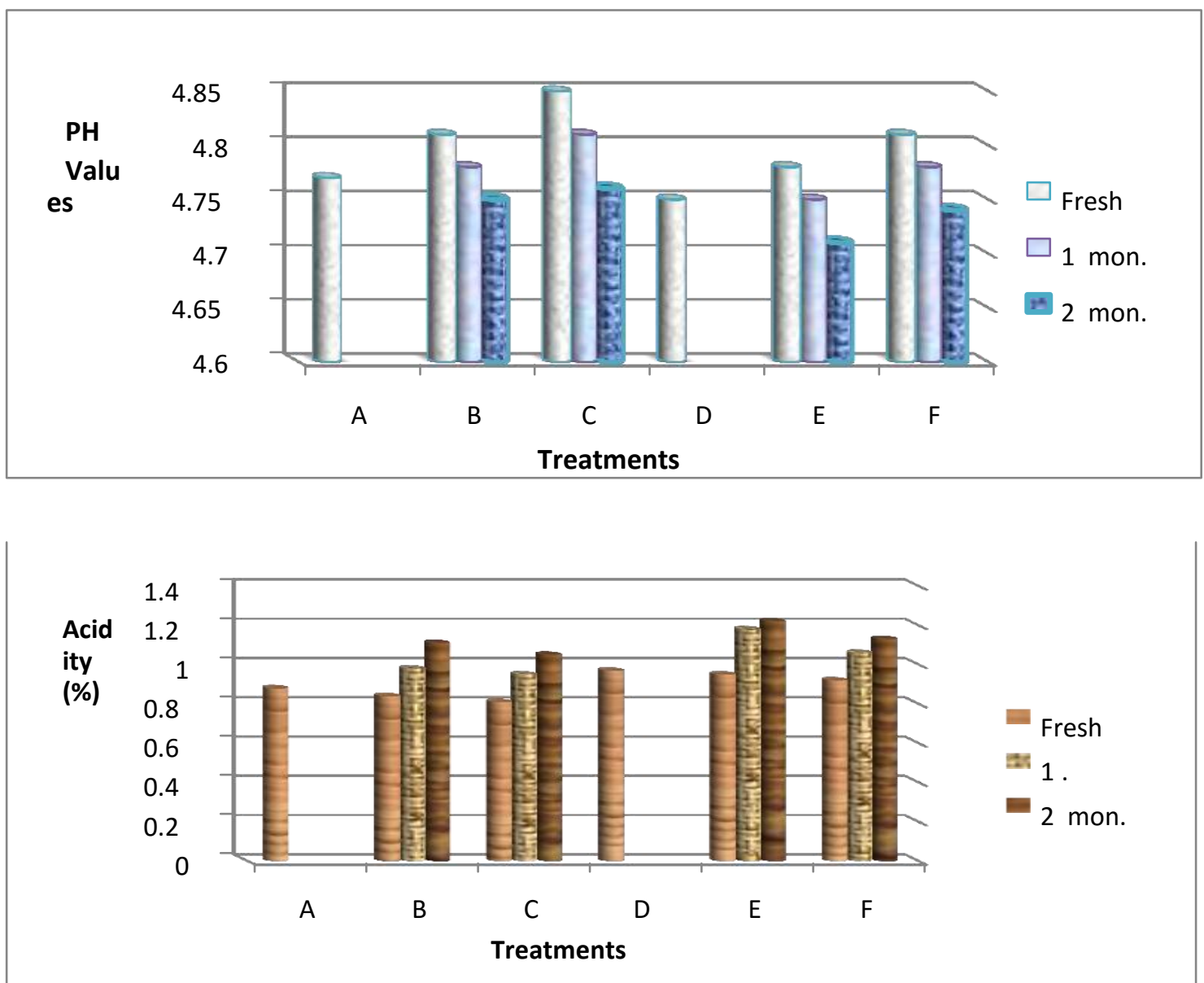

Fig 2. PH value and Acidity (\%) in soy cheese during storage $\left(5 \pm 1^{\circ} \mathrm{C}\right)$ 
Table (3). Microbiological properties (log cfu/g) of soy cheese during storage at $5 \pm 1^{\circ} \mathrm{C}$

\begin{tabular}{|l|l|c|c|c|c|c|c|}
\hline \multicolumn{1}{|c|}{ Strains } & Storage & $\mathbf{A}$ & $\mathbf{B}$ & $\mathbf{C}$ & $\mathbf{D}$ & $\mathbf{E}$ & F \\
\hline \multirow{4}{*}{ Lb. bulgaricus } & Fresh & $7.56 \pm 0.21^{\mathrm{A}}$ & $7.44 \pm 0.11^{\mathrm{Ba}}$ & $7.39 \pm 0.21^{\mathrm{BCa}}$ & $7.64 \pm 0.16^{\mathrm{A}}$ & $7.59 \pm 0.22^{\mathrm{Aa}}$ & $7.47 \pm 0.11^{\mathrm{Ba}}$ \\
\cline { 2 - 8 } & $\mathbf{1 m o n t h}$ & - & $6.99 \pm 0.11^{\mathrm{Ab}}$ & $6.86 \pm 0.20^{\mathrm{Bb}}$ & - & $6.91 \pm 0.19^{\mathrm{Ab}}$ & $6.82 \pm 0.21^{\mathrm{Bb}}$ \\
\cline { 2 - 8 } & $\mathbf{2 m o n t h}$ & - & $6.81 \pm 0.21^{\mathrm{Ac}}$ & $6.63 \pm 0.10^{\mathrm{Cc}}$ & - & $6.72 \pm 0.20^{\mathrm{Bc}}$ & $6.67 \pm 0.10^{\mathrm{Cc}}$ \\
\hline $\begin{array}{l}\text { Str. } \\
\text { thermophilus }\end{array}$ & Fresh & $6.97 \pm 0.11^{\mathrm{A}}$ & $6.78 \pm 0.11^{\mathrm{Ca}}$ & $6.72 \pm 0.11^{\mathrm{Ca}}$ & $6.95 \pm 0.11^{\mathrm{A}}$ & $6.92 \pm 0.11^{\mathrm{Aa}}$ & $6.87 \pm 0.10^{\mathrm{Ba}}$ \\
\cline { 2 - 8 } & $\mathbf{1 m o n t h}$ & - & $6.73 \pm 0.21^{\mathrm{Bb}}$ & $6.66 \pm 0.10^{\mathrm{Cb}}$ & - & $6.86 \pm 0.20^{\mathrm{Ab}}$ & $6.71 \pm 0.10^{\mathrm{Bb}}$ \\
\cline { 2 - 8 } & $\mathbf{2 m o n t h}$ & - & $6.64 \pm 0.10^{\mathrm{Bc}}$ & $6.48 \pm 0.15^{\mathrm{Cc}}$ & - & $6.83 \pm 0.11^{\mathrm{Ac}}$ & $6.53 \pm 0.11^{\mathrm{BCc}}$ \\
\hline \multirow{2}{*}{\begin{tabular}{l} 
Count \\
\cline { 2 - 7 }
\end{tabular}} & Fresh & $6.14 \pm 0.10^{\mathrm{A}}$ & $6.11 \pm 0.11^{\mathrm{Aa}}$ & $6.10 \pm 0.10^{\mathrm{Aa}}$ & $6.16 \pm 0.12^{\mathrm{A}}$ & $6.13 \pm 0.12^{\mathrm{Aa}}$ & $6.10 \pm 0.11^{\mathrm{Aa}}$ \\
\cline { 2 - 8 } & $\mathbf{1 m o n t h}$ & - & $5.95 \pm 0.30^{\mathrm{Ab}}$ & $5.83 \pm 0.11^{\mathrm{Bb}}$ & - & $5.92 \pm 0.11^{\mathrm{Ab}}$ & $5.86 \pm 0.31^{\mathrm{Bb}}$ \\
\cline { 2 - 7 } & $\mathbf{2 m o n t h}$ & - & $5.82 \pm 0.11^{\mathrm{Ac}}$ & $5.76 \pm 0.10^{\mathrm{Cc}}$ & - & $5.81 \pm 0.11^{\mathrm{ABc}}$ & $5.73 \pm 0.20^{\mathrm{Cc}}$ \\
\hline
\end{tabular}

A, B, C \& D and a, b, c \& d: means with the same letter among treatments and the storage period respectively are not significantly different $(\mathrm{P}>0.05)$.
A: Soy cheese made from soy milk (Control)
D: Soy cheese made from $75 \%$ soy milk $+25 \%$ skim
milk B: A treatment brined in $5 \% \mathrm{NaCl}$
E: D treatment brined in $5 \% \mathrm{NaCl} \mathrm{C:} \mathrm{A} \mathrm{treatment}$
brined in $10 \% \mathrm{NaCl}$
F: D treatment brined in $10 \% \mathrm{NaCl}$

Ng et al.,(2008) observed that the number of Lb. bulgaricus FTCC 0411 and $L b$. fermentum FTD 13 bacteria in tofu during 9 days of cold storage was at the level of $10^{7}-10^{8} \mathrm{CFU} / \mathrm{g}$, and the TVC decreased by $1 \log$ order, and $\mathrm{pH}$ slightly changed, what confirms the results of our studies. Also Liuet al., (2006) have observed slow reduction of $\mathrm{pH}$ and the number of probiotic bacteria cells in the brined soy cheese with addition of probiotic Lb. rhamnosus bacteria stored for 30 days at $10^{\circ}$ C.Mesophilic starter cultures may decrease during the prematuration period of cheese, especially in the existence of higher salt content (6-8\%) and $\mathrm{pH}$ of $<5.0$ (Bintsis and Robinson, 2004).

Also, no colonies from coliform bacteria and were free off yeasts and moulds in the control and all brined soy cheese samples either when fresh or during the storage period (30 and 60 days). This reflects the good hygienic standards and sanitary conditions during the cheese making and storage period in brine solutions (5 and $10 \% \mathrm{NaCl}$ )in agreement with that reported by (Nazim et al., 2013) and (Nugusu and Gudisa, 2019) they reported that the total coliform and mold/ yeast count were absent or $<10 \mathrm{CFU} / \mathrm{gm}$.

\section{Texture analysis}

Texture Profile Analysis (TPA) was performed to evaluate the effects of blended $25 \%$ of fresh skim milk in brined soy cheese ( 5 and $10 \% \mathrm{NaCl}$ solution) on the textural properties of the samples at 1,30 and 60 days of storage at $5 \pm 1^{\circ} \mathrm{C}$ (Table 4). 
Firmness parameter recorded increased values at fresh in A, B and C treatments (100\% soymilk) in compared to C, D and E treatments ( $75 \%$ soymilk blended with $25 \%$ skim milk). Park et al., (2005) also observed that a skimmed milk yogurt had a lower hardness value than soy yogurt.

Table (4). Rheological properties of soy cheese during storage at $5 \pm 1^{\circ} \mathrm{C}$

\begin{tabular}{|c|c|c|c|c|c|c|c|}
\hline Properties & Storage & $\overline{\mathbf{A}}$ & B & $\bar{C}$ & D & $\mathbf{E}$ & $\mathbf{F}$ \\
\hline \multirow[t]{3}{*}{ Firmness } & Fresh & $8.05 \pm 0.11^{\mathrm{AB}}$ & $8.13 \pm 0.19^{\mathrm{Bc}}$ & $8.34 \pm 0.16^{\mathrm{Ac}}$ & $7.76 \pm 0.21^{\mathrm{C}}$ & $7.85 \pm 0.20^{\mathrm{Bc}}$ & $7.91 \pm 0.05^{\mathrm{ABc}}$ \\
\hline & 1month & - & $10.15 \pm 0.16^{\mathrm{Ba}}$ & $11.21 \pm 0.11^{\mathrm{Aa}}$ & - & $9.22 \pm 0.11^{\mathrm{Da}}$ & $9.61 \pm 0.10^{\mathrm{Ca}}$ \\
\hline & 2month & - & $9.13 \pm 0.11^{\mathrm{Bb}}$ & $10.36 \pm 0.04^{\mathrm{Ab}}$ & - & $8.17 \pm 0.11^{\mathrm{Cb}}$ & $8.25 \pm 0.03^{\mathrm{Cb}}$ \\
\hline \multirow[t]{3}{*}{ Cohesiveness } & Fresh & $0.55 \pm 0.11^{\mathrm{C}}$ & $0.63 \pm 0.11^{\mathrm{Ba}}$ & $0.72 \pm 0.06^{\mathrm{Aa}}$ & $0.38 \pm 0.10^{\mathrm{F}}$ & $0.41 \pm 0.20^{\mathrm{Ea}}$ & $0.45 \pm 0.11^{\mathrm{Da}}$ \\
\hline & 1month & - & $0.45 \pm 0.04^{\mathrm{Bb}}$ & $0.52 \pm 0.04^{\mathrm{Ab}}$ & - & $0.37 \pm 0.61^{\mathrm{Bb}}$ & $0.38 \pm 0.23^{\mathrm{Bb}}$ \\
\hline & 2month & - & $0.30 \pm 0.31^{\mathrm{Ac}}$ & $0.31 \pm 0.05^{\mathrm{Ac}}$ & - & $0.28 \pm 0.10^{\mathrm{BC}}$ & $0.24 \pm 0.11^{\mathrm{Bc}}$ \\
\hline \multirow[t]{3}{*}{ Gumminess } & Fresh & $2.41 \pm 0.01^{\mathrm{B}}$ & $2.44 \pm 0.10^{\mathrm{Ba}}$ & $2.58 \pm 0.11^{\mathrm{Aa}}$ & $2.23 \pm 0.20^{\mathrm{D}}$ & $2.32 \pm 0.16^{\mathrm{Ca}}$ & $2.38 \pm 0.20^{\mathrm{BCa}}$ \\
\hline & 1month & - & $1.82 \pm 0.21^{\mathrm{Bb}}$ & $1.87 \pm 0.21^{\mathrm{Bb}}$ & - & $1.83 \pm 0.04^{\mathrm{Bb}}$ & $1.91 \pm 0.03^{\mathrm{Ab}}$ \\
\hline & 2month & - & $1.34 \pm 0.11^{\mathrm{BC}}$ & $1.51 \pm 0.21^{\mathrm{Ac}}$ & - & $1.39 \pm 0.10^{\mathrm{BC}}$ & $1.42 \pm 0.26^{\mathrm{ABC}}$ \\
\hline \multirow[t]{3}{*}{ Chewiness } & Fresh & $1.11 \pm 0.10^{\mathrm{C}}$ & $1.13 \pm 0.10^{\mathrm{Ca}}$ & $1.31 \pm 0.08^{\mathrm{Ba}}$ & $1.26 \pm 0.10^{B}$ & $1.53 \pm 0.20^{\mathrm{Aa}}$ & $1.67 \pm 0.10^{\mathrm{Aa}}$ \\
\hline & 1month & - & $0.84 \pm 0.11^{\mathrm{Ab}}$ & $0.86 \pm 0.11^{\mathrm{Ab}}$ & - & $0.67 \pm 0.21^{\mathrm{Bb}}$ & $0.71 \pm 0.20^{\mathrm{Bb}}$ \\
\hline & 2month & - & $0.47 \pm 0.42^{\mathrm{Bc}}$ & $0.52 \pm 0.26^{\mathrm{Ac}}$ & - & $0.35 \pm 0.10^{\mathrm{Cc}}$ & $0.43 \pm 0.06^{\mathrm{Bc}}$ \\
\hline \multirow[t]{3}{*}{ Springiness } & Fresh & $0.45 \pm 0.01^{\mathrm{B}}$ & $0.45 \pm 0.10^{\mathrm{Bc}}$ & $0.51 \pm 0.02^{\mathrm{Bc}}$ & $0.49 \pm 0.03^{\mathrm{B}}$ & $0.53 \pm 0.02^{\mathrm{Bc}}$ & $0.62 \pm 0.02^{\mathrm{Ac}}$ \\
\hline & 1month & -- & $0.57 \pm 0.02^{\mathrm{Cb}}$ & $0.62 \pm 0.03^{\mathrm{Bb}}$ & -- & $0.65 \pm 0.03^{\mathrm{Bb}}$ & $0.77 \pm 0.02^{\mathrm{Ab}}$ \\
\hline & 2month & -- & $0.68 \pm 0.19^{\mathrm{Aa}}$ & $0.78 \pm 0.11^{\mathrm{Aa}}$ & - & $0.82 \pm 0.10^{\mathrm{Aa}}$ & $0.82 \pm 0.10^{\mathrm{Aa}}$ \\
\hline \multirow[t]{3}{*}{ Resilience } & Fresh & $0.49 \pm 0.02^{\mathrm{C}}$ & $0.47 \pm 0.03^{\mathrm{Ca}}$ & $0.69 \pm 0.01^{\mathrm{Aa}}$ & $0.59 \pm 0.03^{\mathrm{B}}$ & $0.21 \pm 0.03^{\mathrm{Ea}}$ & $0.32 \pm 0.15^{\mathrm{Da}}$ \\
\hline & 1month & -- & $0.31 \pm 0.02^{\mathrm{Bb}}$ & $0.44 \pm 0.05^{\mathrm{Ab}}$ & --- & $0.11 \pm 0.02^{\mathrm{Cb}}$ & $0.14 \pm 0.03^{\mathrm{Cb}}$ \\
\hline & 2month & --- & $0.21 \pm 0.02^{\mathrm{Ac}}$ & $0.23 \pm 0.04^{\mathrm{Ac}}$ & --- & $0.06 \pm 0.03^{\mathrm{Bc}}$ & $0.05 \pm 0.24^{\mathrm{Bc}}$ \\
\hline
\end{tabular}

A, B, C \& D and a, b, c \& d: means with the same letter among treatments and the storage period respectively are not significantly different $(\mathrm{P}>0.05)$.
A: Soy cheese made from soy milk (Control)
D: Soy cheese made from $75 \%$ soy milk $+25 \%$ skim milk
B: A treatment brined in $5 \% \mathrm{NaCl}$
E: D treatment brined in $5 \% \mathrm{NaCl}$
C: A treatment brined in $10 \% \mathrm{NaCl}$
F: D treatment brined in $10 \% \mathrm{NaCl}$

Mitra et al., (2013) reported that the hardness of tofu made of soymilk was very high and adding $10 \%$ buffalo milk did not able to alter its hardness value. However, the hardness of tofu samples decreased with increasing percentage of buffalo milk. Data showed increased of Firmness values at 30 days in all treatments of soy cheese samples as affected by brined concentrations, and then decreased at the end of storage. In addition, Cohesiveness, 
Gumminess, Chewiness and Resilience values were decreased during storage period of soy cheese in brined solutions ( 5 and 10\%), while Springiness values increased during of storage resulted in Table 4

Also, Liu et al., (2006) recorded that the addition of $10 \%$ of $\mathrm{NaCl}$ to the curd in soy cheese decreased significantly $(\mathrm{p}<0.05)$ in hardness and cohesiveness of the cheese. .The developed probiotic soy cheese spread samples were harder than dairy cheese spread and had a solid like behavior (Giri et al., 2018). Also texture profile analyses

in a semi-hared soy cheese were similar to a cheese made to the same compositional standards from bovine milk (Chumchuere et al., 2000). Matias et al., (2014) found that the instrumental texture parameters (hardness, adhesiveness, cohesiveness, and gumminess) of soybased cheese products were higher than those of milk-based petitsuisse cheese.

Data agree with Kaminarides et al., (2019) who recorded that cheeses salted in brines of $7 \%, 10 \%$, and $13 \%$ exhibited a continuous gradual increase in hardness throughout storage in brine solutions.

\section{Sensory evaluation}

The sensory characteristics of brined soy cheese made with deferent $\mathrm{NaCl}$ concentrations (5 and $10 \%$ ) during storage 60 days at $5 \pm 1{ }^{\circ} \mathrm{C}$ are shown in Table 5. Statistical analysis showed that the proportion of fresh skim milk (25\%) used for soy cheese improving significantly ( $\mathrm{p}$ $<0.05)$ influenced on sensory characteristics Color, flavor, appearance, texture and aroma scores increased generally at fresh and during storage compared to soy cheese $(100 \%$ soy milk).

Arora and Mittal (1991) reported that addition of skim milk to soymilk (20:80) improved the texture of tofu.

The highest score in all parameters of sensory evaluation were observed in soy cheese treatments at 60 days during storage in 5 and $10 \% \mathrm{NaCl}$ brined, while the lowest values at fresh. The increase in the value of flavor in soy cheese blended with $25 \%$ skim milk was attributed to be completed of storage period by glycolysis, lipolysis and proteolysis processes.

Raja et al., (2014) who recorded that the samples of soy paneer containing 75:25 levels of soymilk and skimmed milk was liked most by the sensory panelists in comparison to other samples.

Flavor can be developed by replacing a percentage of the soymilk with other milk types. Using $30 \%$ or more buffalo milk with soymilk to make tofu improves the flavor (Mitra $\boldsymbol{e t}$ al., 2013).

The colour, taste, flavor and overall acceptability of the West Africa soft cheese (WASC) were significantly $(\mathrm{p}<0.05)$ influenced by the proportions of cow and soy milk ( Chikpah $\boldsymbol{e t}$ al., 2016).

Cheeses brined at $3^{\circ} \mathrm{C}$ were the softest, especially those from the $20^{\circ} \mathrm{C}$ fermentation that had the higher initial $\mathrm{pH}$ and moisture contents (McMahon et al., 2009).

Also, Patil et al., (2015) recorded that the sensory evaluation of soy cheese made by Starter culture (1:1 Streptococcus thermophiles and Lactobacillus bulgaricus) shows that C3 cheese (50\% ) soymilk and 50\% cow milk) shows the good in taste, flavor, colour and texture as compared to the other treatments. 
Table.5. Sensory evaluation of soy cheese during storage at $5 \pm 1^{\circ} \mathrm{C}$

\begin{tabular}{|c|c|c|c|c|c|c|c|}
\hline Properties & Storage & $\mathbf{A}$ & B & $\mathrm{C}$ & D & $\mathbf{E}$ & $\mathbf{F}$ \\
\hline \multirow[t]{3}{*}{ Color } & Fresh & $3.07 \pm 0.16^{\mathrm{D}}$ & $3.10 \pm 0.11^{\mathrm{Cc}}$ & $3.16 \pm 0.19^{\mathrm{Cc}}$ & $3.13 \pm 0.22^{C}$ & $3.22 \pm 0.15^{\mathrm{Bc}}$ & $3.30 \pm 0.11^{\mathrm{Ac}}$ \\
\hline & 1month & --- & $3.32 \pm 0.20^{\mathrm{BCb}}$ & $3.39 \pm 0.10^{\mathrm{Bb}}$ & ------- & $3.51 \pm 0.21^{\mathrm{ABb}}$ & $3.86 \pm 0.18^{\mathrm{Ab}}$ \\
\hline & 2month & ---- & $3.65 \pm 0.16^{\mathrm{Da}}$ & $3.73 \pm 0.21^{\mathrm{Ca}}$ & --------- & $4.23 \pm 0.12^{\mathrm{Ba}}$ & $4.40 \pm 0.21^{\mathrm{Aa}}$ \\
\hline \multirow[t]{3}{*}{ Flavor } & Fresh & $2.11 \pm 0.12^{\mathrm{F}}$ & $2.54 \pm 0.11^{\mathrm{Ec}}$ & $2.79 \pm 0.16^{\mathrm{Dc}}$ & $3.00 \pm 0.50^{\mathrm{CC}}$ & $3.17 \pm 0.14^{\mathrm{Bc}}$ & $3.46 \pm 0.29^{\mathrm{Ac}}$ \\
\hline & 1month & ----- & $2.67 \pm 0.21^{\mathrm{Db}}$ & $2.92 \pm 0.21^{\mathrm{Cb}}$ & ------ & $3.62 \pm 0.11^{\mathrm{Bb}}$ & $3.89 \pm 0.16^{\mathrm{Ab}}$ \\
\hline & 2month & ------ & $3.21 \pm 0.21^{\mathrm{Da}}$ & $3.63 \pm 0.21^{\mathrm{Ca}}$ & -------- & $4.12 \pm 0.21^{\mathrm{Ba}}$ & $4.43 \pm 0.20^{\mathrm{Aa}}$ \\
\hline \multirow[t]{3}{*}{ Appearance } & Fresh & $2.31 \pm 0.11^{\mathrm{D}}$ & $2.35 \pm 0.11^{\mathrm{Dc}}$ & $2.44 \pm 0.21^{\mathrm{Dc}}$ & $3.22 \pm 0.21^{\mathrm{C}}$ & $3.36 \pm 0.12^{\mathrm{BC}}$ & $3.53 \pm 0.20^{\mathrm{Ac}}$ \\
\hline & 1month & ------ & $2.61 \pm 0.20^{\mathrm{BCb}}$ & $2.83 \pm 0.20^{\mathrm{Bb}}$ & -------- & $4.03 \pm 0.21^{\mathrm{ABb}}$ & $4.12 \pm 0.11^{\mathrm{Ab}}$ \\
\hline & 2month & ------ & $3.03 \pm 0.40^{\mathrm{Ca}}$ & $3.01 \pm 0.10^{\mathrm{Ca}}$ & ------- & $4.18 \pm 0.11^{\mathrm{Ba}}$ & $4.33 \pm 0.20^{\mathrm{Aa}}$ \\
\hline \multirow[t]{3}{*}{ Texture } & Fresh & $2.30 \pm 0.16^{\mathrm{F}}$ & $2.46 \pm 0.09^{\mathrm{Ec}}$ & $2.83 \pm 0.11^{\mathrm{Dc}}$ & $3.03 \pm 0.20^{\mathrm{Cc}}$ & $3.24 \pm 0.10 \mathrm{ABc}$ & $3.52 \pm 0.11^{\mathrm{Ac}}$ \\
\hline & 1month & ----- & $2.71 \pm 0.20^{\mathrm{Db}}$ & $3.03 \pm 0.11^{\mathrm{Cb}}$ & ------- & $3.77 \pm 0.11^{\mathrm{Bb}}$ & $3.94 \pm 0.13^{\mathrm{Ab}}$ \\
\hline & 2month & ------ & $2.99 \pm 0.11^{\mathrm{Da}}$ & $3.12 \pm 0.21^{\mathrm{Ca}}$ & ------- & $4.17 \pm 0.11^{\mathrm{Ba}}$ & $4.32 \pm 0.11^{\mathrm{Aa}}$ \\
\hline \multirow[t]{3}{*}{ Aroma } & Fresh & $2.01 \pm 0.20^{\mathrm{E}}$ & $2.15 \pm 0.15^{\mathrm{Dc}}$ & $2.34 \pm 0.20^{\mathrm{Cc}}$ & $2.31 \pm 0.18^{C}$ & $2.54 \pm 0.21^{\mathrm{Bc}}$ & $2.62 \pm 0.20^{\mathrm{Ac}}$ \\
\hline & 1month & ----- & $2.62 \pm 0.19^{\mathrm{Db}}$ & $2.84 \pm 0.21^{\mathrm{Cb}}$ & $\begin{array}{l}----- \\
\end{array}$ & $3.57 \pm 0.11^{\mathrm{Bb}}$ & $3.76 \pm 0.14^{\mathrm{Ab}}$ \\
\hline & 2month & $\begin{array}{l}---- \\
--\end{array}$ & $3.14 \pm 0.11^{\mathrm{Da}}$ & $3.93 \pm 0.20^{\mathrm{Da}}$ & $\begin{array}{ll}---- \\
\end{array}$ & $4.11 \pm 0.20^{\mathrm{Ba}}$ & $4.25 \pm 0.20^{\mathrm{Aa}}$ \\
\hline & $\mathrm{D}$ & 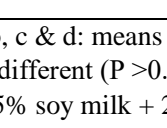 & skim milk & de $f$ & the stora & $\begin{array}{l}\text { respectively } \\
\text { D: Soy }\end{array}$ & \\
\hline
\end{tabular}

brined in $5 \% \mathrm{NaCl} \mathrm{C:} \mathrm{A} \mathrm{treatment} \mathrm{brined} \mathrm{in} 10 \% \mathrm{NaCl}$

F: D treatment brined in $10 \% \mathrm{NaCl}$

The use of $S$. thermophilus in the preparation of other product like cheese, made from soymilks was studied by Hang and Jackson (1967 a,b) with satisfactory results. The obtained product was superior in body and texture with moisture content minor that the elaborated one from the addition of acetic acid or by precipitation with salt. The skimmed milk incorporation, rennin and lactic cultures improved the flavor of the product. The growth of the microorganisms in soymilk improved with the skimmed milk addition that contributes lactose.

Also soybean curd under this ratio (1:2 between CYY-122 and SVV-21) strains have got the highest grade in color, flavor, morphology and taste of sensory evaluation, those advantages were more obvious than other ratio (Jianming $\boldsymbol{e t}$ al., 2013). The role of lactic acid bacteria (LAB) in soymilk fermentation is to produce acid and flavor, and to remove the undesirable beany taste and improve the shelf life of the fermented product (Choi et al., 2015). 
A spreadable soy cheese type that was made by combining Glucono Dalta Lactone (GDL) and Lactic acid bacteria (LAB) fermentation methods exhibited a more stable and less easily fractured structural system, and achieved higher scores of sensory acceptance (Qinghui $\boldsymbol{e t}$ al., 2013).

Data showed samples of brined soy cheese with $25 \%$ skim milk (F treatment) increase statistically significant $(\mathrm{P}<0.05)$ in texture properties than soy cheese $(100 \%$ soy milk $)$ at the end of storage period ( 60 days) at $5 \pm 1{ }^{\circ} \mathrm{C}$.

Cow's milk can be replaced by up to $15 \%$ with soymilk without affecting the sensory characteristics of the cheese (Edima et al., 2014).

In addition, salt plays a very important role in soy cheese, which imparts a salty taste to the product as well as serves to control the enzyme activity, biochemical changes during cheese ripening, and the simultaneous development of the desired flavor and aroma. It inhibits the survival and/ or growth of spoilage-causing, pathogenic and toxin-producing microorganisms.

\section{CONCLUSION}

Soymilk mainly as an important replacer of milk due to lactose intolerance or allergic reaction to cow's milk and as a low-cost source of good quality protein and energy.

Milk combinations have also been used to improve the structure, the beany and chalky odor and flavor of traditional soy cheese types reduces their favor for consumers. Soy cheese produced through fortification of soymilk with skim milk (25\%) exhibited acceptable properties when inoculated with yoghurt starter and maintained mean viable counts of $10^{6}$ $\mathrm{cfu} / \mathrm{g}$ in all soy cheese treatments. The use of brine solutions ( 5 and $10 \% \mathrm{NaCl}$ ) to storage of all treatments at $5 \pm 1{ }^{\circ} \mathrm{C}$ enhanced the shelf life up to 60 days and improving sensory properties of the cheeses.

\section{REFERENCES}

Abd El-Kader Y.I. (2003). Changes in nitrogen fractions of Domiati cheese made with microbial and recombinant rennet's during ripening. Egypt. J. Dairy Sci. 31, 111-124.

Abou Zeid N.A., Hamed A.I., Kebary K.M.K. and Nasser A.A. (2007). Effect of different pickling solutions and storage temperatures on the quality of Domiati cheese during pickling. In: Proc.10th Egypt. Conf. Dairy Sci. Techn.: 401-413. https://www.academia.edu

Ahmad,N.; Li,L.; Yang,X.Q.; Ning,Z.X. and Randhawa, M.A.(2008). Improvements in the Flavour of Soy Cheese, Food Technol. Biotechnol., 46 (3) 252- 261. https://www.cabdirect.org 
Alizadeh,M. and Lavasani,A.R.S. (2013).Effect of different types of milk on some physicochemical and sensory characteristics of Iranian white brined cheese. Annals of Biological Research, 4 (10):6770. http://scholarsresearchlibrary.com/AB...

AOAC (2012). Methods of Analysis. Vol. 1. Agricultural Chemicals, Contaminants, Drugs. 19th ed. Washington D.C.

Arora, S. and Mittal, B. K. (1991). Preparation and evaluation of soy paneer. J. Food Sci. Technol., 28(1): 15-17

Ayyash, M.; Sherkat, M.; Francis, P.; Williams, R. and Shah, N. (2011). The effect of sodium chloride substitution with potassium chloride on texture profile and microstructure of Halloumi cheese. J. Dairy Sci., 94: 37-42. https://doi.org/10.3168/jds.2010-3407

Ayyash, M.M.; Sherkat, F. and Shah,N.P.(2012). The effect of $\mathrm{NaCl}$ substitution with $\mathrm{KCl}$ on Akawi cheese: Chemical composition, proteolysis, angiotensinconverting enzyme-inhibitory activity, probiotic survival, texture profile, and sensory properties. J. Dairy Sci., 95:4747-4759. https://doi.org/10.3168/jds.2011-4940

Bakirci, I.; Kavaz, A. and Macit, E. (2011).Effect of different brine concentrations and ripening period on some quality properties of Turkish white pickled cheese. African Journal of Biotechnology, 10(56):1192511931. DOI: 10.5897/AJB11.647

Banks, J.M. (1992). Cheese In: Early R (ed). The Technology of Dairy Products, VCH Publisher Inc, New York, pp 39-65.

Bintsis, T. and Robinson, R.K. (2004). A study of the effects of adjunct cultures on the aroma compounds of Feta-type cheese. Food Chem., 88: 435-441. DOI:10.1016/j.foodchem.2004.01.057

Bourne, M. C. (2003). Food texture and viscosity: Concept and measurement.

New York/London.

Chikpah, S.K.; Teye, M.; Annor, J.A.F. and Teye, G.A. (2015). Potentials of Sodom apple (Calotropis procera) extract as a coagulant to substitute Alum in soy cheese production in Ghana. Elixir J., 79:30166- 30170. https://ir.ucc.edu.gh > xmlui > bitstream > handle

Chikpah, S. K. ; Ketor,H. and Ayitey,D.(2016). Effect of Different Blends of Cow Soy Milk on Yield, Nutritional and Organoleptic Characteristics of West Africa Soft Cheese (Wagashie) Ghana Journal of Science, Technology and Development, 4(1):40-42. DOI: https://doi.org/10.47881/75.967x

Choi, H.J.; Lee, N.K. and Paik, H.D.(2015). Health benefits of lactic acid bacteria isolated from kimchi, with respect to immunomodulatory effects. Food Sci. Biotechnol., 24:783-789. DOI: $\underline{10.1007 / \mathrm{s} 10068-0150102-3}$ 
Chumchuere, S.; MacDougall, D.B. and Robinson, R.K.(2000).Production and properties of a semi-hard cheese made from soya milk. Int. J. Food Sci. and Technol., 35:577581. http://www.thaiscience.info >

Dagdemir, E.; Çelik, S. and Özdemir, S. (2003). The effects of some starter cultures on the properties of TurkishWhite cheese. Int J. Dairy Technol., 56:215218.DOI:10.1046/j.1471-0307.2003.00103.x

Edima, H.C.; Nji, Q.N.; Awono, E.T.; Abossolo, S.L.D. and Mbofung, C.M. (2014). Optimization of the extraction of soymilk and formulation of softcheese from cow milk and soymilk. Int. J. Biol. Pharm. Allied Sci., 3:1886-1895.

EL-Shouny W.; Abo-Kamar A. and Ragy S. (2013). Characterization of the partially purified plantarcin SR18 produced by Lactobacillus plantarum SR18. Journal of Microbiology, Biotechnology and Food Sciences, 2 (5): 2301-2305. https://www.proquest.com

Erdem,Y.K. (2005). Effect of ultrafiltration, fat reduction and salting on textural properties of white brined cheese. Journal of Food Engineering, 71: 366-372. DOI:10.1016/i.jfoodeng.2004.10.040

Fox, P. F.; Guinee, T. P.; Cogan, T. M. and McSweeney, P. L. H. (2000). In Fundamentals of cheese science: 169-205.

Giri, S.K; Tripathi, M.K and Kotwaliwale, N. (2018). Effect of composition and storage time on some physico-chemical and rheological properties of probiotic soy cheese spread. J. Food Sci. Technol.,

55(5):1667-1674. Doi: 10.1007/s13197-018-3078-1

Grasso, N.; Roos, Y.H.; Crowley, S.V.; Arendt, E.K. and O'Mahony, J.A. (2021). Composition and physicochemical properties of commercial plant-based blockstyle products as alternatives to cheese. Future Foods, 4 (12): 100048 https://doi.org/10.1016/j.fufo.2021.100048

Guinee, T.P. (2004).Salting and the role of salt in cheese. Int. J. Dairy Technol., 57: 99108. DOI: $10.1111 / \mathrm{j} .1471-0307.2004 .00145 . \mathrm{x}$

Guinee, T. P. and Fox, P. F. (2004). Salt in cheese: physical, chemical and biological aspects. General aspects of cheese technology. In Cheese: Chemistry, Physics and Microbiology, Vol. 2. General Aspects, 3rd edn. Fox P F, McSweeney P L H, Cogan T $\mathrm{M}$ and Guinee T P, eds. London: Elsevier. https://www.elsevier.com >

Guven. M. and Karaca, O.B. (2001). Proteolysis levels of white cheeses salted and ripened in brines prepared from various salts. Int. J. Dairy Technol., 54(1): 29-33. DOI: $\underline{10.1046 / J .1471-0307.2001 .00003 . X}$ 
Han, B.Z.; R.R. Beumer, F.M. and Rombouts, M.J.R. (2001). Nout, Microbiological safety and quality of commercial sufu - A Chinese fermented soybean food, Food Control, 12: 541-547. DOI:10.1016/S0956-7135(01)00064-0

Hang, Y.D. and Jackson, H. (1967a). Preparation of soybean cheese using lactic starter organisms. I. General characteristics of the finished cheese. Food Technology, 21:9596.

Hang, Y.D. and Jackson, H. (1967b). Preparation of soybean cheese using lactic starter organisms. II Effects of addition of rennet extract and skim milk. Food Technolog,y 21:97-100.

Hayaloglu, A.A.; Guven, M.; Fox,P.F. and McSweeney,P.L.H. (2005). Influence of starters on chemical, biochemical, and sensory changes in Turkish White-Brined cheese during ripening. J. Dairy Sci., 88: 34603474. https://www.journalofdairyscience.org

Hofi, A.A.; Rabie, A.M.; Farahat, S.E.; Abou el Ella, W.M. and ElShibiny, S.(1976). Yield, quality and chemical composition of Domiati cheese from buffaloes and soy milk mixture. Egyptian Journal of Dairy Science, 4 (2):141.

Hursit,A.K. and Temiz,H.(2000).Factors affecting the properties of Halloumi cheese made from cow and soya milk blends during storage. II. Effect of $\mathrm{pH}$ and brine concentration.Ziraat Fakultesi Dergisi, 15(2):14- 19. https://eurekamag.com

Igyor, M.A.; Igbian, E.K. and Iorbo, C.I. (2006). Effects of soymilk supplement on the yield and Quality of 'Warankashi'. Nigerian Food J., 24(1): 92-97 DOI: $\underline{10.4314 / \text { nifoj.v24i1.33638 }}$

Ismail, M.M. (2005). Manufacture of Domiati cheese from reconstituted skim milk and different types of cream. Egypt. J. Dairy Sci. 33, 247-259.

https://www.researchgate.net

Jeewanthi, R.K.C. and Paik, H.Y. (2018). Modifications of nutritional, structural, and sensory characteristics of non-dairy soy cheese analogs to improve their quality attributes. J. Food Sci. Technol., 55(11):4384-4394. Doi: 10.1007/s13197-018-34083. Epub 2018 Sep 1.

Jianming,W.; Qiuqian,L.; Yiyun,W. and Xi,C.(2013). Research on soybean curd coagulated by lactic acid bacteria. Springer Plus, 2(1):250. https://springerplus.springeropen.com

Kaminarides,S.;Moschopoulou,E. and Karali,F. (2019). Influence of Salting Method on the Chemical and Texture Characteristics of Ovine Halloumi Cheese. Foods J., $8, \quad$ 232. 232 ; https://doi.org/10.3390/foods8070232 
Kayagil, F. and Gurakan, C. (2009). Effects of starter culture combinations using isolates from traditional cheese on the quality of Turkish white cheese. Int. J. Dairy Technol., 62:387-396. DOI:10.1111/j.1471-0307.2009.00493.x

Kirk, R. S. and Sawyer, R. (1991). Pearson's composition and analysis of foods (9th ed.). London: Addison-Wesley Longman, Inc. Chapter 2\& 14.https://www.worldcat.org

Kostoska,M.D.; Velickova,E.; Kuzmanova,S. and Winkelhausen,E. (2015). Traditional white brined cheese as a delivery vehicle for probiotic bacterium lactobacillus casei. Macedonian J. of Chem. and Chemical Engin., 34, (2): 343-350.https://1library.net

Krishna,A. (2003). Physico-chemical characteristics of some new varieties of soybean. Journal of Food Science and Technology 40: 490- 492. https://www.researchgate.net

Lavasani, A.R.S. (2016). Acceleration of White Brine Cheese by Microbial Lipase Enzyme. Int. J. of Innovative Sci., Engin. \& Technol., Vol. 3 Issue 6, June. http://healthdocbox.com

Lee, N.K.; $\quad$ Mok, B.R.; $\quad$ Jeewanthi, R.K.C.; $\quad$ Yoon, Y.C. and Paik, H.D.(2015). Physicochemical and Microbiological Properties of Yogurt-cheese Manufactured with Ultrafiltrated Cow's Milk and Soy Milk Blends. Korean J. Food Sci. An., 35(2): 205-210. DOI:10.5851/kosfa.2015.35.2.205

Liong M. T.; Easa A. M.; Lim P.T.and Kang J. Y. (2009). Survival, growth characteristics and bioactive potential of Lactobacillus acidophilus in a soy-based cream cheese. Journal of the Science of Food and Agriculture, 89(8): 13821391DOI: $\underline{10.1002 / j \mathrm{jfa} .3598}$

Liu,D.M.; Li,L.; Yang,X.Q.; Liang,S.Z. and Wang,J.S.(2006). Survivability of Lactobacillus rhamnosus during the preparation of soy cheese. Food Technol. Biotechnol., 44 (3):417-422. https://www.researchgate.net

.Marshall, R. T. (1992). Standard Methods for the Examination of Dairy Products. American Public Health Association (APHA), Washington, D.C., USA. https://www.scirp.org

Matias, N. S; Bedani, R; Castro, I. A' Saad, S.M.I (2014). A probiotic soy based innovative product as an alternative to petit-suisse cheese. LWT Food Sci. Technol., 59:411-417.DOI:10.1016/j.lwt.2014.05.054

McMahon,D.J.; Motawee,M.M. and McManus,W.R.(2009). Influence of brine concentration and temperature on composition,microstructure, and yield of feta cheese J. Dairy Sci., 92:4169-4179. Doi: 10.3168/jds.2009-2183 
Mitra, J.; Jha, A.; Alam, T.; Singh, D.S.; Ranjan, S.K.; Pathak, S. and Naz, A. (2013). Sensory and textural properties of tofu manufactured by blending buffalo milk. Asian J. Dairy \& Food Res., 32 (2): 135-138. http://arccarticles.s3.amazonaws.com

Nazim, M. U.; Mitra, K.; Rahman, M. M.; Abdullah, A.T. M. and Parveen, S. (2013). Evaluation of the nutritional quality and microbiological analysis of newly developed soya cheese. Int. Food Res. J., 20(6): 3373-3380 https://www.researchgate.net

Ng, K.H.; Lye,H.S.; Easa,A.M.and Liong,M.T.(2008). Growth characteristics and bioactivity of probiotics in tofu-based medium during storage. Annals of Microbiol., 58(3):477-487. DOI:10.1007/BF03175546

Nugusu, Y. and Gudisa, A. (2019). Evaluation of Coagulants on Soy Cheese Making Efficiency Int. J. of Trend in Res. and Develop., 3(1).227-232. doi: $\underline{10.3390 / \text { foods } 8120600 .}$.

Park, D.J.; Sejong,O.; Hyung, K.; Mok,C.; Kim, S.H. and Imm, J.Y.(2005). Characteristics of yogurt-like products prepared from the combinationof skim milk and soymilk containing scarified-rice solution. Intl. J.Food Sci. Nutr., 56 : 23-34. Doi: 10.1080/09637480500082181.

Pastorino,A.J.; Hansen, C.L. and McMahon,D.J (2003). Effect of salt on structurefunction relationships of cheese. J. Dairy Sci., 86: 60- 69. https://doi.org/10.3168/jds.S0022-0302(03)73584-X

Patil, N.J.; Talib, M.I. and Parate, V.R. (2015). Development of Soya Cheese. International Journal of Engineering Research \& Technology (IJERT), 4 (11): 714718. https://www.academia.edu.

Pereira, P.C. (2014).Milk nutritional composition and its role in human health. Nutrition, 30: 619-627. DOI:10.1016/j.nut.2013.10.011

Qinghui, L.;Yuelan, X.; Li, Z. and Jingli, X.(2013). Evaluation of the rheological, textural, microstructural and sensory properties of soy cheese spreads. Food Bioprod $\quad$ Process, 91:429-439. DOI:10.1016/j.fbp.2013.03.001

Raja,J.; Punoo, H.A. and Masoodi,F.A. (2014). Comparative Study of Soy Paneer Prepared from Soymilk, Blends of Soymilk and Skimmed Milk. J Food Process Technol., 5(2): 301. http://omicsonline.org/openaccess/co.

Rathore, S.; Salmero, N.I. and Pandiella, S. (2012). Production of potentially probiotic beverages using single and mixed cereal substrates fermented with lactic acid bacteria 
cultures. Food Microbiology, 30: 239- 244. Doi: 10.1016/j.fm.2011.09.001. Epub 2011 Sep 24.

Rinaldoni, A.N.; Palatnik, D.R.; Zaritzky, N. $\quad$ and Campderro's, M.E. (2014). Soft cheese-like product development enriched with soy protein concentrates. LWT-Food Sci Technol., 55:139-147. https://doi.org/10.1016/j.lwt.2013.09.003

Rotaru, G.; Mocanu, D.; Uliescu, M. and Andronoiu, D. (2008). Research studies on cheese brine ripening. Innovative Romanian Food Biotec., 2, Issue of June 30. https://citeseerx.ist.psu.edu

Sahingil,D.; Hayaloglu,A.A.; Simsek,O. and Ozer,B. (2014). Changes in volatile composition, proteolysis and textural and sensory properties of white-brined cheese: effects of ripening temperature and adjunct culture. Dairy Sci. \& Technol., 94:603623. DOI 10.1007/s13594-014-0185-2

SAS Institute (1990). SAS User's guide/STAT ver. 6.04 Fourth edition SAS Inst. Inc.,Cary,NC.,USA.

Tanteeratarm, K.;Nelson, A.I. and Wei, L.S.(1993). Manufacturing of bland soymilk. In Soybean Extrusion and Soymilk Technology, Soy Food Products and Home Utilization. Urbana-Champaign, IL: University of Illinois, International Soybean Program (INTSOY).

Tharmaraj, N. and Shah, N.P. (2003). Selective Enumeration of Lactobacillus delbrueckiissp. bulgaricus, Streptococcus thermophilus, Lactobacillus acidophilus, Bifidobacteria, Lactobacillus casei, Lactobacillus rhamnosus, and Propionibacteria. J. Dairy Sci., 86(7): 2288-2296. Doi: 10.3168/jds.S0022-0302 (03)73821-1.

Wang,R.Z. and Du,X.X.(1998). The Production of Soy Cheese in China, (Eds.), China Light Industry Press, Beijing (in Chinese).

Wolf, W. J. (1970). Soybean proteins. Their functional, chemical, and physical properties. Journal of Agricultural and Food Chemistry, 18(6): 969-976. https://doi.org/10.1021/jf60172a025

Yilmaztekin,M.; Özer,B.H. and Atasoy,F. (2004). Survival of Lactobacillus acidophilus LA-5 and Bifidobacterium bifidum BB-02 in white brined cheese, International Journal of Food Sciences and Nutrition, 55 (1): 53-60. DOI:10.1080/09637480310001642484

Zielińska,D.; Kamińska,A. and Krajewska,D.K.(2015). Development of tofu production method with probiotic bacteria addition. J. Microbiol. Biotech. Food Sci., 4 (6): $485-$ 490.DOI:10.15414/jmbfs.2015.4.6.485-490 